\title{
Attitude to labor in Russian and Uzbek cultures (on the example of folk proverbs)
}

\author{
Isaeva Gulnora Abdukadirovna \\ Senior Lecturer of Department of Russian Language and Literature \\ Philology faculty Bukhara State University \\ gulung@mail.ru
}

\begin{abstract}
The article is devoted to the study of Russian and Uzbek proverbs about labor. As a result of the research, five categories were identified: attitudes toward work, effort, timely work, skill, and patience. The authors of the article identified similar and distinctive features in the proverbs of the studied languages.
\end{abstract}

Key words: proverb, paroemia, ethnicity, labor, culture, language.

\section{I.Introduction}

Proverbs and sayings originated in ancient times and were created by many generations of people, developed over the centuries and since then accompany a person in everything throughout the history of his existence. Knowledge of proverbs and sayings from different countries enriches vocabulary, introduces people to the wisdom of the people, helps to learn many features of the language, develops memory. In addition, proverbs and sayings decorate speech, make it more imaginative and interesting.

\section{II.Literature review}

Proverbs help to master the figurative structure of the language, "to see the unity and originality of linguistic units" [1, p. 89], help to understand the attitude of representatives of a particular people to certain areas of human life. They always come to our minds when talking, to the occasion. Proverbs and sayings contain direct advice and suggest what to do in any situation. They are the most curious genre of folklore. And also in these short, figurative sentences containing a complete thought, new foreign words are easier to remember.

It is possible to single out such properties of proverbs as: instructive content and the ability to express in a concise form an observation that summarizes the experience and life path of the cultural community under consideration [5]. Proverbs of different languages often do not coincide, using them we see how different peoples on different continents in different ways, but at the same time, equally rethought similar life situations, phenomena of different objective reality, and at the same time characterizing them with peculiar features. Each culture has its own characteristics, which are reflected in the proverbs.

\section{III.Analysis}

Proverbs and sayings walk with us throughout our life. This research is devoted to Russian and Uzbek proverbs, sayings, their similarities and differences, on the topic of "work". This allows you to get better acquainted with the national culture of Russia and Uzbekistan, to understand how and how similar these peoples are and how they differ. The study of folk proverbs and sayings of the cultures under consideration allows you to improve your knowledge of the English language, to get the opportunity to get acquainted with the customs to deeply penetrate and study the native language (in our case, Russian and Uzbek), as well as to understand the national characteristics of each nation, which contributes to the formation of tolerance and a sense of respect for their own and other culture [4].

In the process of studying proverbs in Russian and Uzbek, it is interesting that there are many proverbs in different languages that are similar in meaning, despite the fact that cultures are different, have their own characteristics and values. Proverbs originated in ancient times and they reflect ideas related to work, life and culture of the ethnic group. Comparison of proverbs of different peoples allows to define and reveal the spiritual and moral image of peoples, their aspirations and ideals, the way of their people's life. We studied Russian (30) and Uzbek proverbs (17). A comparative analysis of the considered paremias allows us to trace the attitude of a person to work in different cultures, the desire of a person to show physical and intellectual strength, to use his knowledge and experience to achieve certain results. Russian and Uzbek proverbs were formed in different historical conditions, social organizations, beliefs and systems of actions, conditions of socio-economic development. Comparative analysis of the considered paremias allows you to divide the proverbs into the following categories, reflecting their essence and specificity (Table 1): 1. Attitude to work.

The first category is "Attitude to work". The attitude, in turn, can be either positive or negative. Subgroup "Diligence" or "Positive attitude to work." In this subgroup, it is understood that the attitude is expressed in the best qualities and traits of a person. The main aspect of this subgroup is love of work. An example is the following proverb in the Uzbek language: Ish ustasidan qo'rqadi [6, p.35] (The work is afraid of its master). This proverb reflects such character traits as, conscientiousness, skill, the need not just to do the job, but to do it in the best possible way. Here we see a person's attitude to his work, his love for work, respect and diligence in work.

You can also notice that the proverbs in the Uzbek and Russian languages differ in their word construction, but they have the same meaning and meaning. The second interesting fact is that the proverb in the Uzbek language is translated 
into Russian literally, and this proverb is the original proverb in Russian. In this subgroup, proverbs reflect such a quality in a person as the ability to positively relate to the process of labor activity, showing activity, initiative, conscientiousness, enthusiasm and satisfaction with the labor process itself: Measure seven times, cut once [2], Yetti o'lchab bir kes [6, p.38].

The following proverbs, which can be attributed to this subgroup, are the Russian proverb: Spring pours water in the river, labor adds to the price of a person [9] and an Uzbek proverb: Daryo suvini bahor toshirar, odam qadrini mehnat oshirar [6] (Spring pours the river, labor glorifies human). It can be seen here that an analogue can be found for some proverbs in all three cultures, but there are proverbs for which there are no analogues, due to the fact that the characteristics of cultures differ and it is not always possible to find analogs of proverbs of different languages. This is due to the historical development of countries, with their cultural values, as well as their different origins and spheres of their use in the future.

\section{IV.Discussion}

Subgroup "Laziness" or "Negative attitude to work." This subgroup can also be called an indifferent attitude; it includes such character traits as laziness, negligence, which are expressed in a negligent attitude towards work, in the formal performance of tasks. On the topic of laziness, in this category there are many proverbs (in Russian - 8 proverbs, and in Uzbek - 4 proverbs. Proverb in Russian: Lazy Fedorka always has excuses. [2] Proverb in Uzbek: Donoga ish shon-u shuhrat, nodonga ish-g'am-u kulfat [7] (Work for the clever is glory and honor, and for the stupid (lazy) grief and suffering.) Here we see that proverbs are different in all three languages. In Uzbek and Russian, proverbs are similar, but only differ in that the proverb in Russian is used as a certain image of "Fedorka". Laziness is very often used in proverbs for children and schoolchildren. Since it is of an educational nature that condemns human shortcomings, such as: laziness, lack of accuracy, dishonesty. These proverbs not only play a huge role in the development of speech and children, but also activate their vocabulary. Category: "Effort". This category contains proverbs with a positive attitude towards work.

The Russian proverb "You can't even get a fish out of the pond without difficulty," which prove that results can be achieved only if you make a certain effort, and sometimes even sacrifice something. And the equivalent of the Russian proverb is in the Uzbek language: Hovuzdagi baliqchani ham mehnatsiz tutib bo'lmaydi [6, p. 38] (A fish cannot be easily pulled out of a pond). We also see similarities in the fact that in the analogs of proverbs in Uzbek and in Russian, honey is used as the desired result, in Uzbek мед is translated as, asal(honey). And in the analogs of proverbs in Russian and Uzbek languages, fish is used, in Uzbek, fish is translated - baliq.

An analogue of this proverb is the proverb in the Uzbek language: Ishlamagan tishlamas [7] (A person who does not work does not eat). The Uzbek people are characterized by such a character trait as hard work. The Uzbeks have long been engaged in agriculture, crafts and trade. People are able to grow good crops practically in the desert. Accordingly, therefore, perhaps, the Uzbeks modestly call themselves the most hardworking in Central Asia, which is what this proverb says in Uzbek. Kun g'amini sahar ye, yil g'amini bahor ye [6] (At dawn, if you work hard - enough for a day, in spring you work hard - you will feed for a whole year). In the three cultures we have chosen, timely completion of the work is important.

These proverbs imply that you need to prepare for everything in advance so as not to get into awkward situations and to be ready and collected at the right moment. This worldly wisdom is very useful if you follow it, thus saving time and money. These proverbs reflect a conscientious, or in other words, a positive attitude towards work. Category: "Craftsmanship". Skill is understood as the ability to perform a particular job or craft with high quality. That is, if an employee does not know his business, then he will not be able to make friends with his tools, and they will not help him in any way. Analogue in Russian - Master is stupid - the knife is dull.[9]

The meaning of the proverb is similar. If the master is stupid, then he will not undermine the knife. We did not find an analogue in the Uzbek language, but we will definitely continue our search. Also in this category can be attributed to the proverb The work of the master is afraid[2], which we have already mentioned above. We also referred this category of proverbs to a positive attitude towards work. Category: "Patience". The word "patience" is such an ability to calmly, restrainedly wait for any events or results. This quality helps to achieve success in any life situation.

An analogue in Russian is the proverb - Water and stone wears away[2]. Here water is associated with a person, since it persistently and regularly makes a movement, that is, it flows, and thus, over time, can destroy the rock. So a person can achieve a lot if he is patient and put some effort into the matter. In the Uzbek people, patience is associated with embroidery, which every woman does.

Embroidery is considered the national symbol of the Uzbek people. Unlimited patience is required for this art form. In the Uzbek language, the proverb about patience sounds like this: Toqatliga tog 'lar egar boshin[7] (The mountains will bow before the patient). If there is a choice between work and pleasure, then the British prefer the former. Rest is seen as a reward after work done. An analogue to this proverb in Russian is the floorboard, popular and often met by all of us, Business time is an hour of fun. [2] This proverb instructs you to devote more time to work or something else than fun. In the Uzbek language, the analogue of this proverb is the floorboard Yoshlikda bergin mehnat, qariganda bergin davlat [6] (Labor - in youth, rest and bliss - in old age). Which also makes it clear that you can calmly rest in old age, but while you are young, you have strength, you need to work. Proverbs about work occupy a significant place in the cultural heritage of Russian and Uzbek languages. Labor is an integral part of the life of the people. The culturological approach to the study of proverbs highlights the need for comparing different national cultures reflected in languages. Labor in the linguistic 
picture of this or that people represents only one of its many components. An analysis of Russian proverbs shows that work is positively assessed in Russian society. Idleness and laziness are used only in the negative meaning of proverbs. The constructive or creative power of labor forms a certain pattern in which a positive attitude towards work, a willingness to work efficiently and productively is noticeable.

\section{V.Conclusion}

An analysis of proverbs showed that proverbs with a positive attitude towards work prevail in the speaking concept. Careful execution of the work will stand out in proverbs. The British evaluate the worker for work, skill, and laziness, in their opinion, leads to poverty and hunger. In general, Russian and Uzbek people respect the masters of their craft who professionally do their job. Analysis of Uzbek proverbs shows that labor is one of the main components of the Uzbek people. Labor ennobles a person - this is the motto of the Uzbek people to work. Based on the foregoing, it can be concluded that Russian, and Uzbek folk sayings share the opinion that work is one of the main components in human life.

\section{References:}

1. Volozhaninova A.E. Phraseological units with the "bear" component / A.E. Volozhaninov, L.G. Yusupov // Terra Linguae: Sat. scientific. Art. - Issue. 3. 0 Kazan: Kazan Publishing House. University, 2017. - Pp. 87-89.

2. Dal V.I. Proverbs of the Russian people / V.I. Dahl. - M .: Eksmo Publishing House, NNN Publishing House, 1879 .-$660 \mathrm{p}$.

3. Dubrovin M.N. English and Russian proverbs and sayings / M.N. Dubrovin. - M .: Education, 1993 .-- 349 p.

4. A.V. Zorina The role of multicultural education in the formation of ethnic tolerance among university students (on the example of a foreign language) / A.V. Zorina, M.R. Shaimardanova // Bulletin of the Kostroma State University. Series: Pedagogy. Psychology. Sociokinetics. - 2018. - No. 2. - Pp. 132-135.

6. Sidorkova G.D. Pragmatics of paremias: proverbs and sayings as speech actions / G.D. Sidorkova. - Krasnodar, 1999 .- 249 p.

7. Suvonkulova H. Ozbek khalq maqollari / H. Suvonkulova. - Toshkent: Adabiyot uchunlari, 2014 .-- 152 p.

8. Uzbek proverbs and sayings [Electronic resource]. - Access mode: URL: http://fmc.uz/maqollar.php Date of access 28.04.18

9. Lingvister [Electronic resource]. - Access mode: URL: https://lingvister.ru/blog/no-sweetwithout-sweat-angliyskieposlovitsy-o-trude Date of treatment 04.20.18

10. Proverbs and sayings about labor [Electronic resource]. - Access mode: URL: http://sbornikmudrosti.ru/poslovicy-ipogovorki-o-trude/ Date of treatment 04/18/18 